\title{
RHETORIC TURN AND MEDIEVAL HISTORY: A LOOK INTO EUROPE AND USA
}

\author{
Researcher Dario Internullo (University of Rome-3) \\ E-mail: dario.internullo@virgilio.it
}

Professor Marcus Baccega (Federal University of Maranhão)

E-mail: marcusbaccega@uol.com.br

That historiography is indebted to a «linguistic turn» may today be taken for granted, and appears to be almost banal. Historiographic essays, methodological introductions, disciplinary discussions describing the developments of European and American historiography in the second half of the twentieth century, all of them agree in identifying an important turning point in the 1960s, the time when research began to be increasingly influenced by linguistic and language studies. The same thing is true in practice, given that no good research today would be conceivable without a thorough analysis of textual construction of its written sources 1 . Instead, less well known and therefore less obvious is to affirm that between that «linguistic turn» and today's research there have been further moments of development and reflection, which have led to refine methodologies, rethink some basic assumptions, extend the scope of some acquisitions to disciplines so far remained at the margins of those developments. This is the case of the intellectual phenomenon known to various scholars as the «rhetorical turn».

What is the «rhetorical turn»? Basically, it is an awareness of the limits of objectivism and materialism that, starting from the Enlightenment, influenced, and in some cases structured, many scientific, social and humanistic disciplines. Some scholars, mostly American social scientists strongly influenced by European intellectuals such as Jacques Derrida and Roland Barthes, realized that scientific communities are influenced by appeals to auctoritates, traditions, conventions, intuitions, anecdotes and aesthetic care no less than by those rigid formal and deductive logics and by those sets of impartial data that we are still used to associating with scientists today. Following Thomas Kuhn in his The Structure of Scientific Revolutions, they realized that very often those scientific communities look much more like religious groups than detached intellectuals with brilliant minds; likewise, those scientific revolutions and paradigm shifts are much more like religious conversions than carefully considered and well-reasoned shift in scientific practices2. Such an awareness has thus generated particular attention to mechanisms of persuasion that make knowledge changes possible. In other words, it put rhetoric at the center of the debate. «What can rhetorical theory teach us about how to adjudicate among competing values, or prescriptions, or knowledge claims?». This is the question those scholars have posed to themselves and to their colleagues, near and far. Guided by Herbert W. Simons, they 
were thus able to identify a real «rhetorical turn» in the «growing recognition of rhetoric in contemporary thought, especially among the special substantive sciences. It means that the special sciences are becoming increasingly rhetorically self-conscious»3 3 .

As they matured such reflections, which came together in a volume published in 1990, those scholars were well aware that they had not created that phenomenon but, more simply, they realized that they had revealed an intellectual movement that had begun some time earlier but was particularly evident at that moment. One of them, Dilip Parameshwar Gaonkar, has effectively identified a double dimension in this turn. On the one hand, an explicit dimension coincides with the work of those who have explicitly recognized the relevance of rhetoric for contemporary thought and have used rhetoric as a critical and interpretative tool. On the other hand, an implicit dimension concerns production and reflection of all those who were little aware of the rhetorical lexicon and on disciplines inherent in communication, but even so recognized the importance of formal and persuasive aspects of the discourse starting from problems internal to their specific disciplines, no matter whether scientific or humanistic. According to Gaonkar, the internal dimension is much more important than the external one, due to the empirical processes that characterize it and involve, not only philosophers and experts in literary theory and criticism, but also scholars like Walter J. Ong and Tzvetan Todorov: perhaps not all will agree in defining them as historians à part entière but, of course, all will agree in affirming that they have practiced historical research4.

The presence of history in the «rhetorical turn» is not surprising for two reasons. The first reason is that the vast majority of sources that historians have to deal with are usually elaborated by one or more senders for one or more recipients, with the aim of persuading the latter to do or to accept something. This persuasive dimension is clearly present in written sources, but it is also present in the visual ones, which in fact have been well valued from this point of view by many scholars, on top of which is Peter Burke5. The second reason is that rhetoric, i.e. «the study and practices of persuasion» 6 , «l'art de persuader et la science du bien dire»7, often tends to have parasitic relations with other disciplines. It therefore finds a particularly suitable host in the prismatic and multidisciplinary dimension of history.

But what exactly did the «rhetorical turn» mean for historians and particularly for historians of the Middle Ages? One could speak in general of a double movement, which became evident starting from the early 1990s and decidedly accelerated in the last ten years. On the one hand, rhetoric has acquired a deeper and a more concrete temporal and contextual dimension thanks to a new narrative: it is no longer a technique promoted by the Greeks in Antiquity, interrupted during the Middle Ages and recovered by Humanism, but a discipline that has transformed from Antiquity to present day according to a continuum rich in nuance and to temporal, cultural and social variations. On the other hand, like other disciplines, even as history, after having long despised rhetoric, because it is opposed to the Enlightenment scientific methodologies, research has returned to dialogue with it by acquiring new research tools useful both for analyzing and questioning sources and for constructing its own discourses. Medieval history, and medieval history of Europe in particular, played an important role in this evaluation. Given the intense relations between history and diplomatics, i.e. the discipline that studies historical documents from a formal point of view, it could be said that in a certain sense medieval history was more ready than other disciplines to accept rhetoric. In addition to this, medieval European history has played a pivotal role in 'unlocking' the historical dimension of rhetoric. As I said, until the last quarter of the 
twentieth century the dominant narrative was that of an «art of persuasion» very widespread in Antiquity, but which vanished in the Middle Ages and was rediscovered by humanists at the beginning of the Modern Era. Nothing could be a greater falsehood, and historians have well noticed it: in the Middle Ages, rhetoric pervaded many areas of human action, starting from the teaching of systems of rhetoric, passing through the writing of documents and literary works up to liturgy, preaching, assemblies and so on. After all, the articles published in this dossier of Brathair are all indebted to this revaluation, and on their own make a significant contribution to it. Since - except for my mistake - a reflection on these developments in European and American medieval history has not yet been produced, I believe it is useful in these pages to propose a brief illustration. It could constitute a first historiographic orientation on the subject. I need to anticipate that it is not possible, in this case, to establish a direct derivation of these researches from the explicit awareness summarized in the American volume published in 1990. We deal, rather, with a complex, composite process, rich in nuances and also developed, in many cases, from reflections internal to the discipline or to a single research itinerary. Nevertheless, the spread of historiographic topics appears to be coherent to the point of suggesting a real cultural movement. Given their international dimension, I will focus on historiographical fields rather than on individual national historiographies.

A point that is common to all areas, with USA in advance compared to Europe, is the extension of the rhetoric object to historical disciplines starting from literary, philosophical and social disciplines. The first historiographical areas that have benefited from this extension are Renaissance Italy and Byzantium. The reason is quite clear: Renaissance Italy explicitly recovered the rhetoric of the Greco-Roman period, whereas Byzantium is the direct heir of the Greco-Roman structures from which rhetoric was born. But, from there, its extension covered several other areas of Europe, in particular France, Germany, England and Spain - first in the late medieval period, more recently in the early and high medieval ones. In most of these researches, rhetoric was part of a binomial, that is, it was observed in relation to other aspects of human action, but one can also observe a development of rhetoric as a specific object of historical research.

Among the more in-depth topics there is undoubtedly the relationship between rhetoric and politics, directly derived from the late twentieth-century research on ideologies and propaganda in the Middle Ages. Beyond Byzantium, the research focused mainly on communal Italy and on the struggle between the German empire and the papacy in the thirteenth century. The studies on communal Italy were inaugurated by Enrico Artifoni, who, in the 1990s, sparked the attention of political historians towards characters and texts that had been totally ignored until that moment, as is the case of Boncompagno da Signa, Albertano da Brescia and their works. At the same time, Artifoni showed that political practices of thirteenth-century Italy were pervaded by the art of the word, to which Italians were educated through handbooks of ars dictandi and ars arengandi. After him, Enrico Faini, Lorenzo Tanzini and Florian Hartmann further articulated the reflections by extending them to the entire communal period (twelfthfourteenth centuries) and bringing a magnifying glass closer to the specific relationships between city assemblies, rhetorical education of participants, epistolary and historiographical production. Research on empire and papacy also used similar methodologies: after reflecting at length on ars dictaminis, Peter Herde, Laurie Shepard and Benoît Grévin showed that from the thirteenth century the rhetorical dimension of public epistolary production, i.e., the production of documents that were read aloud in 
assemblies, was at the center of ideological and political constructions of the two institutions and more generally of the greater European monarchies. More recently, Mayke de Jong has explored France during the Carolingian era, drawing attention to the relationship between the polemical intellectual production of the monk Radbert, his rhetorical strategies, his audience, and the consent towards sovereigns during the ninth century8.

A topic closely linked to the political one is the relationship between rhetoric and documentary production. Reflections on rhetorical aspects of medieval documents took shape even before the «rhetorical turn», thanks to diplomatic studies that started with Heinrich Fichtenau, if not earlier, focused on the more literary sections of public documents such as the arengae. The intersection between these older studies and the new rhetorical awareness has meant that, from around 2000, not only researchers in diplomatics but also historians dealt more systematically with the persuasive dimension of medieval written sources. Starting from a complete re-evaluation of sources such as the epistles, these scholars have understood that, within medieval chanceries, notaries and officers sought the maximum effect of rhetoric for their texts, with the help of tools such as literary manuscripts of classical authors and, above all, model-letter collections. Furthermore, that rhetoric effect found its raison d'être in the public reading of documents in highly ritualized contexts, such as assemblies. The ancient and resistant barrier between diplomatics/history and literature has thus begun to crumble. At the heart of these reassessments are the studies of Benoit Grévin and Fulvio Delle Donne, but important steps have also been produced thanks to collective works, such as a French one on the language of Western and Byzantine acts or an Italian one on epistolary correspondence in Italy. The most investigated documentary productions are those of the papacy and the empire between the twelfth and fifteenth centuries, but recently there have been many new openings: Maria Isabel Alfonso Anton and David Aller Soriano have studied the Spanish fueros between the eleventh and thirteenth centuries, Brigitte Resl the twelfth-century Italian cartularies, Adele di Lorenzo the Italian Greek acts of the Norman period, Dario Internullo the communal epistles of Rome, Pierre Chastang and François Otchakovsky-Laurens the thirteenth-century statutes of Marseille, Adrien Roguet the French and German documents of the twelfth century, Thomas W. Smith, Matthew Phillips, Helen Killick, Linda Clark and others the English petitions and documents of the thirteenth-fifteenth centuries, Benoît Grévin and Sébastien Barret the French royal acts in the fourteenth century9.

Moving on the relationship between rhetoric and groups, first of all, one should note that already in the early 1980 s there was in Italy a conference on the relationship between rhetoric and social classes. Since the 1990s the discourses have developed further, on the one hand around the formation of ethnic-religious groups, as is the case of the early medieval Bulgarians studied by Lilia Metodieva, or the late medieval Georgian church studied by Barbara Schellewald; on the other hand, around the construction of social groups or genders. Vincent Serverat, in the footsteps of Georges Duby, has studied the rhetorical construction of social classes in Castile, Catalonia and Portugal through a corpus of over 400 texts; François Menant and Enrico Faini explored the concept of populus in Italy and Europe between the eleventh and thirteenth centuries, coming to the conclusion that, even before a social class, populus designates a political program aimed at framing urban and rural communities within precise institutional frameworks, first episcopal and then municipal; Francesco Stella revealed a cultural circuit between teachers of rhetoric, hagiographic production and the 
emergence of civic identity in the communal cities of Bologna and Arezzo between the twelfth and thirteenth centuries. As far as genres are concerned, the development of research around late medieval women, especially those of higher social level, is truly remarkable: this is the case for instance of the studies led by Liz Oakley Brown and Louise J. Wilkinson on the rituals and rhetoric of queenship between the Middle Ages and the Modern Era, those of Rüdiger Schnell on the relationship between gender and rhetoric in the Middle Ages and in the early Modern Era, or those of Nuria Gonzalez Sanchez, Jane Couchman, Ann Crabb on the rhetoric, persuasion, and female epistolography at the end of the Middle Ages 10.

Another particularly practiced theme concerns the relationship between rhetoric and images. Although already practiced by Jacob Burckhardt and Johan Huizinga, historical studies on images have greatly benefited from the twentieth-century reflections on photography, more generally on images, creating in the 1990s a fruitful field of study. I refer here to the works that explicitly use the concept of rhetoric in their research on images: Suzanne Lewis studied the narrative rhetoric of Norman Bayeux tapestries; Thomas Dittelbach and Beat Brenk studied paintings and sculptures of the palatine chapel in Palermo during the Norman period; Nirit Ben-Aryeh Debby and Marco Folin focused respectively on the persuasive aspects of the «images of the Saracens» and on the civic functions of buildings an monuments in Florence in the late Middle Ages; Olga Perez Monzon, Matilde Miquel Juan and Maria Martin Gil have contextualized and unveiled the rhetorical construction of the funeral monument of Alvaro de Luna $(\dagger 1453)$ in the cathedral of Toledo, a monument aimed at redeeming the memory of a Spanish officer who was publicly killed under the accusation of sorcery; Mary Carruthers led a collective work on medieval artistic production (lato sensu) aimed at applying the concept of performance to authors and public, as well as at reflecting on the persuasion strategies implemented by 'non-verbal' enterprises such as the architectural, figurative, musical and liturgical ones, with particular attention to late medieval France and England. As I said, these are the most aware studies of the rhetorical dimensions of images and monuments, but there are many researchers who have used similar methodologies. In addition, especially in Germany and France, there have been several collective reflections on the «rhetoric of images» in the Middle Ages11.

The encounter between rhetoric and religious history was fruitful as well. In this sense, the research focused above all on the relationship between rhetoric and preaching. Some seminal ideas seem to have come from French historiography around Jacques Le Goff between the late 1970s and the 1980s: a collective work published in 1980 focused on the rhetorical exemplum as a basis for investigating the histoire des mentalités between Antiquity and the Middle Ages, which was followed by a work by Le Goff himself on the relationship between exemplum and the rhetoric of preaching. Also in this case the 1990s witnessed to a growth in intensity of such research: starting from those early French works Nicole Bériou explored the persuasion of late medieval preaching in France with dozens of articles, recently collected in a volume; Bériou led together with Jean-Patrice Boudet and Irène Rosier-Catach a collective research on Le pouvoir des mots au Moyen Âge, focused on virtus verborum in the most diverse cultural practices of the Middle Ages, from preaching to theological writing, from miracles to curses up to magic; Michael Menzel has published a book focusing on the rhetoric of historical exemplum in late medieval artes praedicandi and sermons; Carlo Delcorno concentrated on medieval Italian preaching from many points of view, from 
exemplum to ecclesiastical politics, from the literary dimension to the linguistic one; Nicolangelo D'Acunto investigated the political rhetoric of the main actors in the Investiture Conflict, as well as in religious order in the thirteenth century; Gian Luca Potestà studied the prophetic rhetoric of the Minor Friars in relation to Gioachimism; Francesca Romoli explored the communication strategies of Slavic preachers between the eleventh and thirteenth centuries, adopting a comparative perspective that took into account both the Western world of artes praedicandi and Byzantium; Antonio Sennis dealt with the persuasion strategies of monastic supernatural visions in Italy in the eleventh and twelfth centuries; in the wake of Bériou, Christian Grasso illustrated the relationship between papal politics, preaching and the crusades in the thirteenth century; Victoria Smirnova and Marie-Anne Polo de Beaulieu reflected on the Cistercian collections of exempla in Germany during the fifteenth century12.

Such rhetorical and discursive dimensions - not only of medieval texts themselves, but also pertaining to our historiographic operation - have not passed unheeded by in the studies of scholars not strictly bound to rhetorical studies or approach. It is, par excellence, the case of Joseph Morsel, professor and researcher at the University of Paris-1 - Panthéon Sorbonne, whose theoretical reflections recover a great range of intellectual interests and topics. We should like to highlight some of his writings, specially his Le diable est-il dans les détails? L'historien, l'indice et le cas particulier ("Is the devil in the details? The historian, the signal and the particular case", 2019) and Traces, quelles traces? Réflexions pour une Histoire non passéiste ("Traces, what traces? Reflections for a non-backward-looking History", 2016), among many other pieces of work. Morsel is also a strong interlocutor of Flavio de Campos and Hilário Franco Júnior, along with Eliana Magnani, Daniel Russo and Dominique IognaPrat. He also has valuable essays on the matter of archives and diplomatics, in the light of historical theory, here we will mention Histoire, Archives et Documents - vieux problèmes, nouvelles perspectives ("History, Archives and Documents - old problems, new perspectives", 2020), but there are many others.

Although emerged from the traditional narrative (see above) the studies that have dealt with the relationship between rhetoric and Humanism are decidedly important from a historiographical point of view. Thanks to a greater awareness of the 'historicity' of rhetoric, they have managed to rethink deeply that cultural movement. Among the main players in this renewal are Marc Fumaroli, Ronald Witt and Clémence Revest. Fumaroli has the merit of placing the debates on style and forms of speech, promoted by the humanists themselves in the fifteenth and sixteenth centuries, in a more concrete perspective, thus raising the awareness of many historians towards the subject. In the wake of Paul Oskar Kristeller, Ronald Witt then has rediscovered the links between medieval and humanistic culture, identifying their trait d'union in the rhetorical style of ars dictaminis practiced by Italian notaries and teachers of rhetoric, especially those who lived in Florence and Padua. Lastly, Clémence Revest was able to retrace ex novo the entire humanist movement, using public and private letter sources and observing its expansion through stylistic networks that not only from Florence, but also from papal Rome spread first in Italy and then pervaded whole Europe, inducing intellectuals to abandon ars dictaminis for a new classicizing style based on Cicero. That style in turn would have influenced the ways of thinking culture to the point of profoundly modifying educational programs of Europe13.

Those illustrated here are of course not all the historiographical fields that were formed through the «rhetorical turn», but they are certainly the most practiced. Rather 
than dwelling on other developing topics, such as the relationship between rhetoric and judicial practices, rhetoric and music and rhetoric and medicine, I find it more useful to conclude on rhetoric as a historiographical theme in itself. There are two trends that can be detected in the studies of the last three decades. On the one hand, the ancient binary of rhetoric as an argument and as a method of literary disciplines has by no means vanished after the «rhetorical turn» in history. Indeed, it seems that the «rhetorical turn» has also refreshed literary studies with a new strength, as it is demonstrated by a recent volume on Dante and rhetoric, edited by Luca Marcozzi. The same can be said for studies on medieval education: given that rhetoric was part of the arts of trivium since the early Middle Ages, there are countless researches that have deepened the mechanism of learning transmission of the «science du bien dire». We should mention the most recent collective studies on medieval universities, in particular those promoted by Joël Chandelier and Robert Aurélien, involving scholars such as Benoît Grévin and Clémence Revest: they have well incorporated the most recent contributions of French historiography on rhetoric. Similarly, the most recent studies on the so-called artes poetriae, promoted by Gian Carlo Alessio and Domenico Losappio, have clearly identified the schooling and rhetoric dimension of these manuals, long neglected by research, providing further insights for eliminating the border between history and literature. On the other hand, and I come here to the second trend, rhetoric as a scientific object has not only entered with new vigor in numerous historical researches, ranging once more from Byzantium to Europe, but has also undergone an interesting transformation: research has passed from the study of the theory of rhetoric to the study of rhetoric in practice, according to a process similar to that which led political history to pass from institutions to the relationship between rulers and ruled. Particularly indicative, in this sense, are the studies promoted by Floriam Hartmann on the functions of eloquence in communal Italy; the ones by Georg Strack and Julia Knödler on concepts, practices and diversity of medieval and Renaissance rhetoric; by Benoît Grévin and Anne-Marie Turcan-Verkerk on ars dictaminis in all its forms; those by Irene van Renswoude on rhetoric of free speech from the second to the tenth century - the latter also being effective in breaking down the disciplinary barrier between Late Antiquity and the Middle Ages, highlighting historical and cultural consistency of the «first millennium» well illustrated by Garth Fowden. If we adopt this broader chronological perspective, it is finally worth mentioning the ERC-funded project coordinated by Peter Riedlberger on the late antique conciliar proceedings: being focused on rhetorical and communicative aspects that lie behind the complex manuscript tradition of the proceedings, it could provide many methodological insights to the study of political and judicial acts and speeches of the Middle Ages 14.

\section{Rhetoric Turn and Medieval History. A look into Brazil.}

Notwithstanding the fact that some really good researches on Rhetoric have been carried out in Brazil in the last decades, which gave rise to some mandatory readings for students and postgraduate researchers, the field is still to be deepened. As a matter of fact, should we set up a brief archeology of Brazilian pieces of work on Rhetoric and Human Sciences, we would necessarily come across initial writings in legal and literary studies. 
Indeed, the first major influences from the Linguistic Turn of the 1980s was exerted in all areas of Human and Social Sciences, especially Anthropology and Law, yet the properly called Rhetoric Turn came about recently and found a large critical fortune in Philosophy of Law. In this ballast, we can mention a prime book by Professor Tércio Sampaio Ferraz Júnior, Law, Rhetoric and Communication (Direito, Retórica e Comunicação, 1979), which features a thought-provoking dialogue with his former mentor at the University of Mainz (Germany), Theodor Viehweg (1907-1988). Actually, Viehweg was responsible for this inaugural approach to Legal Philosophy in Topics and Jurisprudence (Topik und Jurisprudenz, 1953), by linking up Rhetoric, Dialectics and Law in a very original reflection.

Sampaio Júnior's work has also brought about an entire "rhetorical" tradition in Legal Studies in Brazil, particularly at the University of São Paulo (USP), for which the Faculty of Law - Faculdade de Direito do Largo de São Francisco - has proved to be an actual hatchery. For instance, some significant writing on Law and Rhetoric have been put forth by José Eduardo Faria - Political Rhetoric and Democratic Ideology (Retórica Política e Ideologia Democrática, 1982)

A first and not unimportant binding with History was to be perceived in Sampaio Júnior's work, mainly concerning the idea of History, Crisis and Politics by Hannah Arendt in her The Human Condition of 1958. Viehweg also temporally precedes all the New Rhetoric (Nouvelle Rhétorique) championed by Chaïm Perelment (1912-1984) and Lucie Olbrechts-Tyteca (1899-1987) in Treatise of Argumentation - The New Rhetoric (Traité de l'Argumentation - La Nouvelle Rhétorique), Law and Anthropology have preceded History in terms of adopting the rhetorical method. Henceforth, the first attempts to provide History and Literary Theory with an innovative method couched in rhetorical formulation has come from Legal Philosophy.

Nevertheless, it seems that legal-philosophical and sociological approaches have been prone to reduce the manifold dimensions of Rhetoric to the sense of Forensic Oratory, which draws roots in Cicero's De Oratore, with few regards to Aristotle.

Soon there will be a book by Professor José Reinaldo de Lima Lopes (University of São Paulo), named Course of Philosophy of Law: Law as Practice, expected for 2021, where an entire chapter is devoted to Rhetoric. Lima Lopes' great merit, in our view, is his sensibility and sensitiveness to realize that Aristotle must still be looked upon as the most important auctoritas in the field of Philosophy and History. For Professor Lopes, Rhetoric could not be reduced, at all, to its oratory dimension. It is a matter of urgently retrieving its contents as the ars of producing veracity in social relationships and providing legal practice with rational and reasonable arguments and mostly the capacity to formulate truthful judgements and assertions.

Thus, his book is going to endow us with reflections that are vital both to the realms of Cultural History and History of Law, which confirms the author's primacy in History and Philosophy of Law in terms of Brazil and internationally. It is not at all by chance that one of the very leading historians of our time takes exactly the same pathway. In fact, in his History, Rhetoric, and Proof (The Menahem Stern Jerusalem Lectures) (Rapporti di Forza - Storia, Retorica, Prova, 1999), Ginzburg tells of the trend to approach Rhetoric through a Ciceronian view. It hinders historians and other researchers to unfold the huge heuristic potential of Aristotle's doctrine of Rhetoric as the art (in the sense of $\tau \dot{\varepsilon} \chi \vee \eta$ ) that grants us the ways to formulate proof to our speeches, i.e., the way to elaborate truthful reasoning. 
Before making its way towards History in Brazil, Rhetoric were also widely influenced by Literary Studies. However, this time, the linkage to History turned out to be much more profound and fruitful. There are, to our mind, two founding names for these studies, especially regarding the medieval period, who are Professor Márcia Mongelli and Professor Yara Frateschi Vieira.

First comes a book, organized by Professor Mongelli (University of São Paulo), called Trivium and Quadrivium - The Liberal Arts in Middle Ages (Trivium e Quadrivium - As Artes Liberais na Idade Média, 1999), wherein Mongelli has written a chapter herself, entitled "Rhetoric: the virtuous elegance of well saying" ("Retórica: a virtuosa elegância do bem dizer").

Moreover, in her turn, Professor Frateschi Vieira has composed an already classic article drawing attention to the rhetorical dimensions of narrative, "A B Bee in the Rain': rhetorical proceedings of narrative", which was published in Alfa - Revista de Linguística, 16th volume, 1970.

Both scholars organized a collection of medieval writings and narratives featuring rhetorical motives and topics ranging from the 11th to the 15 th century and entailing auctoritates both from Islam and Latin Christendom. Their excellent Introduction to the collection itself can perfectly act out as a detailed guidebook for rhetorical studies and maiden researches in the area, as was our own case. The collection book is nominated Medieval Aesthetics (Estética Medieval, 2001).

A colleague and friend of Mongelli and Frateschi Vieira, Professor Maria do Amparo Tavares Maleval, is as well to be regarded as a major researcher on Medieval Rhetoric, which we can promptly infer from her book Fernão Lopes and Medieval Rhetoric (Fernão Lopes e a Retórica Medieval, 2010). The three of them, Mongelli, Frateschi Vieira and Maleval, with the support of the Brazilian historian Hilário Franco Júnior, stand for the very idealizers and founding members of the Brazilian Association of Medieval Studies (ABREM), which has existed since 1996.

One specific citation is as well mandatory: a very recent piece of work by Dante Tringali (University of São Paulo), Ancient Rhetoric and Other Rhetorics (A Retórica Antiga e Outras Retóricas, 2013), which stands for a culminating moment of his research career, having succeed two other masterpieces in Brazil, i.e. The Poetics of Horace (A Arte Poética de Horácio, 1983) and Introduction to Rhetoric: rhetoric as literary criticism (Introdução à Retórica: a retórica como crítica literária, 1988).

Furthermore, it is relevant to point out the works, specifically dedicated to Rhetoric, by José Luiz Fiorin (University of São Paulo), with his recent Rhetorical Figures (Figuras de Retórica, 2014), and Luiz Rohden (UNISINOS), with The Power of Language: The Rhetoric of Aristotle (O Poder da Linguagem: a Arte Retórica de Aristóteles, 1997).

Recently, much attention is drawn to the researches of Artur Costrino (UFOP), whose main subject is the rhetorical production of Alcuin of York (c.735-804), principally couched in his De Rhetorica from around the year 790, drawing its roots to the Palatine Court of Charlemagne.

Nonetheless, the very ground of Rhetorical Studies in nowadays Brazil definitely lies upon two major authors, João Adolfo Hansen (University of São Paulo) and Alcir Pécora (University of Campinas). They respectively wrote The Satire and the Spirit: Gregório de Matos and 17th century Bahia (A Sátira e o Engenho: Gregório de Matos e 
a Bahia do século XVII, 1989) and The Machine of Genders (Máquina de Gêneros, 2001), both having given rise to a huge number of studies, monographic pieces of work, dissertations and books on Rhetorics and Belles Lettres.

Their great influence has not been restricted to the field of Literary Theory or Critics. The domain of Cultural History has gained a great deal from it in Brazil, as we can prove by resorting to the great work of Alírio Carvalho Cardoso (Federal University of Maranhão) on Rhetorics and Epistolography, mainly pointing out to his article, composed in partnership with Alcir Pécora, "An art lost in the Tropics: Jesuit's Epistolography in Maranhão and Grão-Pará (17th-18th centuries)" ("Uma arte perdida nos Trópicos: a epistolografia jesuíta no Maranhão e Grão-Pará, Séculos XVII-XVIII”), published in the 8th volume of the Revista de Estudos Amazônicos (2012).

Although not a tout court historian, we should like to mention the writing of Fábio Palácio (Federal University of Maranhão) on Rhetorics and Economics, in partnership with Cristiano Capovilla, named "We are, in fact, hell: on method and rhetoric in Economics" ("Somos, de fato, o inferno: sobre método e retórica na Economia"), published in Revista Princípios, 8th volume, 2016. This piece of critical work draws an important interface with Economic History and has proved much influential in our Northeast part of Brazil, especially in Maranhão, where Brathair is officially held.

At last, directly pertaining to the realm of Medieval History, there are the researches by Professor Flavio de Campos (University of São Paulo), which encompass the theme of games and ludic modalities, wherein he handles Aquinas' retrieval of the Aristotelean virtue named eutrapely (ST. II-IIae, q.168), also appearing in the Comments to Aristotle's Ethics (IV,16). It is indeed the virtue ordaining and balancing human appetite to experience fun.

It is certainly worthy catching a glimpse of the work of Ricardo da Costa (Federal University of Espírito Santo), specially The Rhetoric in Antiquity and the Middle Ages from the perspective of eleven philosophers (2019) and his painstaking translation of Ramon Llull's New Rhetoric (1301).

Finally, there has been the recent work by Marcus Baccega (Federal University of Maranhão) addressing the rhetorical and sacramental dimensions of chivalric romans from the Central Middle Ages in the German regions of Central Europe. We should like to mention his book The Sacrament of the Holy Grail (2020), in which a reflection on medieval sacramentology and rhetoric is developed by leading off from German Arthurian narratives of the 13th century.

Baccega's researches are deeply influenced by the French medievalist Professor Joseph Morsel (University of Paris-1 - Panthéon Sorbonne), whose theoretical reflection on reading and interpreting medieval writings and also on Methodology and Theory of History have turned out to be a great source of scientific inspiration. The first wave of inspiration and enthusiasm for the rhetorical approach to medieval romans and chivalric novels has come from Professor Flavio de Campos, who has permanently been sensitive to the need of defining other ways of focusing medieval narratives. A great influence is also exerted by the work of the aforementioned Professor Benoit Grévin (University of Paris-1 - Panthéon Sorbonne), whose researches deal directly with Rhetorics in Middle Ages, as already explained in the first part of this Editorial. 


\section{Contributions to this Edition}

It is actually on this ballast that the articles found in this edition of Brathair explore the manifold relationships between the Rhetoric Turn and Human Sciences, evincing all its heuristic potential to Medieval History.

Therefore, our edition, nominated Rhetoric in Middle Ages, features at first the dense article by Professor Benoît Grévin (LAMOP/University Paris I), L'ars dictaminis et la poésie: questions théoriques et pratiques (XIe-XIVe s.) (The ars dictaminis and poetry: theoretical and practical questions), which lays emphasis on the epistolographic character of medieval rhetorics, thus stressing a major dissemblance to ancient rhetoric. Very relevant for both personal and political purposes, letters were the sources of rhetorical expression. From the 11th to the 15th centuries. This is why the so-called Artes Poetriae and Artes Dictaminis feature so many intersections and convergences, being one of their functions the teaching on how to compose decorous pieces of writing for communication. The article explores as well the metrical and properly poetical traits of these letters, gracing our Edition with a true Lectio on the subject, as the readers shall certainly remark.

Our second article is by Professor Alberto Cotza (University of Florence), Le orazioni nel Liber Maiorichinus (Prayers in the Liber Maiorichinus), which poses very pertinent questions on language and speech in the 12th century Pisan society through a truly exegetical approach of a text barely known to Brazilian scholars. It is the Liber Maiorichinus, an epic poem dealing with the history of the Balearic war, which the Pisans and other Christians conducted against the Muslims in Ibiza, Minorca, and Mallorca (1113-1115), as the author lectures.

Such a sophisticated exegesis, in terms of Linguistics and Rhetoric is to be found as well in Professor Clara Barros' (University of Porto) reflection entitled A construção da imagem do poder em textos jurídicos da Idade Média peninsular (The construction of the image of power in legal texts of the Middle Ages). Drawing precisely upon the theoretical and methodological interface between Discourse Pragmatics and the multiple versions pertaining to the Theories of Argumentation, Barros seeks to analyze some strategies of the persuasion characteristic of Afonso X - the Wise's legislative work which reveal a certain relationship between rhetorical construction and political power in the Peninsular Middle Ages (in the 13th and 14th centuries). Focus is here laid upon the argumentum ab auctoritate in the Primeyra Partida (1265) and the Foro Real (c.1280), which allows the author to explain in detail and by means of graphs the ideological structure of Iberian medieval societies in the 13th and 14th centuries.

By dint of his expertise in the field of Rhetorics and Historiography, the Italian researcher Dario Internullo (University of Rome-3) proposes a dense reflection about the links between Historical Theory, Diplomatics and Rhetorics regarding the legal practice of process citation in the commune of Rome during the Late Middle Ages. His article is called A citação na chancelaria - a comuna de Roma no Medievo (Citation in Chancellery - The commune of Rome in Middle Ages) and presents the very potential of rhetorical analysis not only to the sciences of language and to interpreting documents and testimonies (in this case, sources contrived and made circulate by lay and clerical 
authorities), but to casting a complex historiographical problem to hard political and legal documentation in order to achieve what we would dare to call a Total History.

Providing very qualified concreteness to our purpose of an interdisciplinary dialogue, and once again exposing how Historiography owns much to Literary Theory in terms of rhetorical studies, we present the text by Professor Márcia Mongelli (University of São Paulo), which analyses the connection between Rhetoric and Poetry in the troubadours' and trouvères' love songs from Central Middle Ages. The poem chosen in her A "retórica cortês" e suas sutilezas (Courtly Rhetoric and its subtleties) is Senhor Genta ("Gentle Lady"), composed by the Galician-Portuguese troubadour Joan Lobeyra (c. 1233-1285), which would grant the poetic matter and topics to the notorious 16th century chivalric novel Amadis de Gaula (1508), by Garci Rodríguez de Montalvo.

This early 16th century Portuguese edition was preceded by a Castilian one from 1496, yet both of them take roots in an original Portuguese version that would have been conceived by Vasco Lobeira during the reign of Dom Fernando I (1367-1383). Mongelli's piece of work actually acquires poetic tones and builds up a past-present analysis by resorting to the poems of Amor em Leonoreta (1951) by the major neosymbolist Brazilian poet Cecília Meireles, who devoted part of her poetic production to retrieving our medieval roots.

In the present edition of Brathair, we are also graced at the presence of an article by a much prominent scholar in the domain of Medieval Rhetoric, Professor Maria do Amparo Tavares Maleval (State University of Rio de Janeiro), whose contribution is dedicated to a rhetorical analysis of the great figure of Portuguese drama in Late Middle Ages. The article is entitled A Retórica no Purgatório de Gil Vicente (Rhetoric in the Purgatory of Gil Vicente). It is certainly a discussion on the playwright Gil Vicente, whose play Auto da Barca do Purgatório ("Purgatory barge auto", 1518) is here the theme for manifold perceptions concerning the classical parts of rhetoric, mainly the elocutio, dispositio and inventio. Thus, traits of humor, comic scenes and strict morality and virtues are interlarded in the plot, along with the threefold conception of the Other World. For historians interested in unravelling the late medieval imaginary about death and afterlife, this text is definitely a must.

Appealing to the Early Middle Ages - or Late Antiquity, as the author advocates Professor Ana Paula Tavares Magalhães (University of São Paulo) brings us a reflection about the conversion itinerary pertaining to Saint Augustin, from 382 to 386 . Her piece of work could not have been nominated in a different manner: A Ars Rhetorica de Agostinho de Hipona na narrativa das Confissões (The Rhetoric Art of Augustine of Hyppo in the narrative of The Confessions). Such testimony is couched in the most well-known opusculum by the Doctor Gratiae, The Confessions, written between 397 and 400 , which poses the many pathways and drawbacks of a former Roman pagan from the classis senatorialis in his, so to say, "itinerarium mentis in Deum". Our present comparison takes roots forward to Saint Bonaventure's treatise of the year 1259, as a way to highlight the role played by Magalhães as a specialist in Franciscan studies, whose highbrow qualities allow her to identify and dissect Saint Augustine's work itself and his huge theological and philosophical influence over the Franciscan writers. This is precisely the reason why the author resorts to the mystic of conversion regarding Augustine, as a manner to uncover a meaningful pattern for the studies on Augustin's Rhetoric techniques, as well as it provides a paradigm of symmetry between Augustin's life and the History of the Church, her specialty. 
Also dealing with the erudite culture layers in Central Middle Ages, Professor Sérgio Feldman (Federal University of Espírito Santo), a highlighted specialist for Jewish history in the Middle Ages proposes a reflection on a wise Jew from the Hispania of the three religions. As a matter of fact, the article Yehuda Ha-Levi: a retórica na polêmica religiosa no século XI-XII - O Livro de Cuzari (Iehudá Ha-Levi: rhetoric in the religious polemics in the 11th-12th centuries - The Book of Cuzari) portrays and dissect the many rhetoric disputationes in Iberia on the "true" or "best" religion. This way, Feldman narrates and casts a historiographical problem on the Book of Cuzari, the narrative of the conversion of the Khazars to Judaism. So, a literary work that endeavors to demonstrate that the Jewish religion is superior to that of its competitors, even if the Jewish people were subject to an oppressed minority condition.

At this moment of our edition, we come across a very original reflection by Professor Terezinha Oliveira (State University of Maringá) about the statute of language as a subject and the philosophy of language in Aquinas, by making use of the Summa Theologiae: Quaestiones 176 and 177 - IIa-IIae . The article A Retórica como Princípio do Intelecto e da Linguagem em Tomás de Aquino (Rhetoric as principle of the Intellect and Language in Thomas Aquinas). Having been a profound specialist in the thought both theological and philosophical - of Aquinas for decades, Oliveira poses herself the challenge of dissecting the role and philosophical locus of Rhetoric as a grounding pillar of his reasoning on language and the unity of the human intellect. This papers also handles Aquinas' reading of Aristotle as a rhetoric auctoritas, basically by leading off from Aquinas' Commentary on Aristotle's On Interpretation very well, which demonstrates the connection between language and the intellective appetite of human beings.

Further reflection on highbrow culture in High Middle Ages is provided by a young and much talented scholar from the Federal University of Ouro Preto, Professor Artur Costrino, who has spent many years investigating the work of Alcuin of York De Rhetorica (c.790). As the author pinpoints in his Disputatio de rhetorica et virtutibus de Alcuíno de York: crítica às recepções modernas e hipótese sobre a organização dos dois assuntos do diálogo (Alcuin's of York Disputatio de rhetorica et virtutibus: criticism of modern receptions and a hypothesis about the organization of the two subjects of the dialogue), this dialogue by Charlemagne's most famous teacher had a huge favourable acceptance and circulation in its period. Nonetheless, De Rhetorica seems to have been forgotten by scholarly research in our time. Therefore, Costrino's piece of work shall surely open up new investigation lines in Medieval Rhetorics and the practices of power by the time of first Renovatio Imperii under Charlemagne and in the aftermath.

In contrast to Costrino's analysis of De Rhetorica as an ars of prudence and exercising virtues, Professor Leandro Rust (University of Brasília) stresses warfare and violence in Middle Ages, attempting to think the theme of bloodshed over. His article Retórica Sangrenta: pensar a comunidade na Idade Média (Bloody Rhetoric: thinking Community in Middle Ages) challenges the reader to rethink and cast doubt on the common images we all would, almost automatically, associate with our period of study and research. It is not a matter of whittling down that violence and bloodshed were ubiquitous, yet rather of spelling out its significance in terms of medieval communities. Such is the aim of Rust in this reflection, which leads off from a crime that took place in England in the 13th century, which sets bloodshed, authority, power and crime together as signs to be deciphered. 
We have in this edition a text that merges History, Literary Theory and Philosophy, approaching a female voice of wisdom in the Late Middle Ages, Christine de Pizan. The Book of the City of Ladies (1405) is probably her most celebrated piece of work and here stirs up a reflection on Education, on women's condition in our own time and in Middle Ages. This is why Professor Luciana Eleonora Deplagne (Federal University of Paraíba) endeavors to formulate a hermeneutic exercise regarding the Socratic idea of maieutic applied to the struggle of women for more autonomy and rights to perform tasks usually thought of as masculine. Therefore, the idea of knowledge being born in a metaphorical scene with three "midwifes" and the «parturient » apprentice is here presented as a Platonic dialogue between Lady Reason, Lady Justice and Lady Righteousness and the narrative persona of Christine de Pizan.

The following article can be properly situated in the typically medieval intertextuality drawn between hagiographic narratives (Vitae), rhetorical topics and homiletics in Early Middle Ages/Late Antiquity. Called Retórica e Hagiografia: a Vita Martini (Rhetorics and Hagiography: the Vita Martini), by post-doctoral researcher Glícia Campos (State University of Rio de Janeiro), the text bethinks the rhetorical aspects of Christian persuasion and exemplarity of conduct by the saints. The basic dialogue of the main part of the corpus is held - and it could not be any different - with the auctoritas of Aristotle and his Rhetorical Art. The writing of Campos bears resemblance, concerning its aims, to Grévin's contribution, since the scope of language analysis ranges from Rhetorics to Hagiography, having the idea of conversio morum as a common trait, just like the dictamina.

Moreover, in a sort of dialogue with Mongelli's writing, Doctor Ana Luiza Mendes aims at investigating the rhetorical traits of King Dom Dinis's poetry. The author regards him as the greatest Portuguese troubadour and a hugely erudite man of his days. Though not intended to be any "biography" of Dom Dinis, this A retórica trovadoresca de Dom Dinis, o rei que não tira a coroa ao trovar (The troubadours' rhetoric of Dom Dinis, the king who did not take out the crown to composse troves) features a kind of historiographic individual inquiry that can be sorted out and demonstrated by the traces and indices left by Dom Dinis in his love songs. Our readers shall find it amusing to uncover this enormous cultural heritage hidden in the royal figure, who gives way to catching a glimpse of all the social structures and processes.

A thought-provoking reflection on the relationships between History and Rhetoric, having the Regnum Francorum and the transition from the Carolingian to the Capetians, is adduced by Professor Bruno Casseb Pessoti (Federal University of Western Bahia). Addressing the Historiarum Libri Quatuor by the monk Richer of Saint-Rémi, A retórica como suporte da 'verdade' em um livro de História do século X (The rhetoric as support for 'truth' in a 10th century History book) explores the close bonds between the activity of writing History and persuasive topics handled to legitimate the new dynasty. In this sense, Pessoti achieves a refined combination of Rhetorics and Political History, without renouncing to ensemble view, thus being able to fathom social sensibilities related to Frankish monarchy at the passing of the millennium.

The last thematic article was written by Professor Marcus Baccega (Federal University of Maranhão). Named A Demanda do Santo Graal: Retórica e Poder no Milênio (The Quest of the Holy Grail: Rhetoric and Power in the millennium), the paper aims at proposing a Total History of the passage of the first millennium of the Common Era, by resorting to the Holy Grail as a metaphor, at the level of the ideological 
representation, of such moving totality. By the way, the Holy Grail purports many dimensions, even heretic ones, of the central-medieval imaginary, defined by the theological concepts of sacraments and sacramentals, point out to a trace of mentality ranging from the Cathars and Templar Knights to the so-called erudite culture. The basic idea is that the Holy Grail acts out (in the sense of having social agency) as a strong symptom of the Immitatio Christi and the Vita vere apostolica as mental traces which are set into dispute both by the Pontifical Reform and by the centralizing attempts of the Holy Roman Empire.

In the section reserved to articles with free choice themes, we also begin with a medievalist of value, Professor Carlile Lanzieri Júnior (Federal University of Mato Grosso). His piece of work, called $\mathrm{O}$ lugar da infância medieval nos escritos dos mestres Alain de Lille (1128-1203), João de Salisbury (c.1115-1180) e Adelardo de Bath (1080-1152) (The place of the medieval childhood in the writings of the masters Alain of Lille (1128-1203), John of Salisbury (ca.1115-1180) and Adelard of Bath (10801152), is much thought-provoking as well. Lanzieri draws upon the lectiones of the aforementioned masters and the emphasis they used to lay on Grammar, in order to demonstrate that there was a specific social locus for children and teenagers during the Middle Ages. Therefore, it is a challenging writing in terms of the traditional historiography of the 20th century and even most historians nowadays.

The second article of free choice subject is a contribution by Professor João Batista Bitencourt (Federal University of Maranhão), who lectures Theory of History and History of Historiography at UFMA. The writing deals with a theoretical reflection about History as a scientific discipline and the historiographical operation, by leading off from a famous and intriguing film of the year 1995, nominated Se7en, shot by David Fincher. The author resorts to the philosophy of History of Walter Benjamin in order to weave a joint reasoning about time, event and narrative and to think the implications of the past we retrieve to the present of the historian.

We should also like to offer a very good translation of The New Rhetoric (1301) by Ramon Llull, composed by a major specialist in the life, thought and relationships of the Mallorcan philosopher. It is here a very well carried out and painstaking translation that will certainly give rise to and assist a great number of new researches on the life and work of Llull. The choice could not have been better and we thank Professor Ricardo da Costa for this gift granted to Brathair.

Last, but not least, there is the recension written by a junior researcher of Brathair, Thaís dos Santos, about the recent book Les Gaulois. Variétés et Légende (2018) de Jean-Louis Brunaux which matches the initial and permanent thematic scope of our journal. There are still very few researches on Celts in terms of Historiography, being the Celtic culture more widely known to Literary Theory and Archeology. This well contrived recension - we do hope - is going to wake up new professional callings to such studies.

We wish you all a great reading experience with our present edition. 


\section{Bibliography}

Acerbi 2011: S. Acerbi, Concilios y propaganda eclesiastica en el siglo V. Estrategias de persuasion y adquisicion del consenso al servicio del poder episcopal, in Propaganda y persuasion en el mundo romano. Actas del VIII Coloquio de la Asociacion Interdisciplinar de Estudios Romanos, Madrid 1-2 diciembre 2010, ed. by. Bravo Castaneda, R. Gonzalez Salinero, Madrid 2011, 295-308

Alessio-Losappio 2018: Le «poetriae» del medioevo latino. Modelli, fortuna, commenti, ed. by G.C. Alessio, D. Losappio, Venezia 2018

Alfonso Anton 2007: M.I. Alfonso Antón, La rhétorique de légitimation seigneuriale dans les fueros de León (XI $-X I I I^{e}$ siècles), in Pour une anthropologie du prélèvement seigneurial dans les campagnes médiévales (XI $I^{e} X I V^{e}$ siècles). Les mots, les temps, les lieux. Colloque tenu à Jaca du 5 au 9 juin 2002, ed. by M. Bourin, P. Martinez Sopena, Paris 2007, 229-252

Aller Soriano 2009: D. Aller Soriano, El fuero como retorica. De religquia positiva a canon identitario, «Sancho el Sabio» 31 (2009), 55-80

Artifoni 1993: E. Artifoni, Sull'eloquenza politica nel Duecento italiano, «Quaderni medievali» 35 (1993), 57-78

Artifoni 1994: E. Artifoni, Retorica e organizzazione del linguaggio politico nel Duecento italiano, in Le forme della propaganda politica nel Due e nel Trecento, ed. by P. Cammarosano, Roma 1994, 157-182

Artifoni 2002: E. Artifoni, Boncompagno da Signa, i maestri di retorica e le città comunali nella prima metà del Duecento, in Il pensiero e l'opera di Boncompagno da Signa, ed. by M. Baldini, Signa 2002, 23-36

Artifoni 2011: E. Artifoni, L'oratoria politica comunale e $i$ «laici rudes et modice literati», in Zwischen Pragmatik und Performanz. Dimensionen mittelalterliche Schriftkultur, ed. by C. Dartmann, T. Scharff, C.F. Weber, Turnhout 2011, 237-262

Barret-Grévin 2014: S. Barret, B. Grévin, Regalis excellentia. Les préambules des actes des rois de France au XIV siècle (1300-1380), Paris 2014

Bartuschat 2004: La Persuasion, ed. by J. Bartuschat, Grénoble 2004

Bériou et al. 2014: Le pouvoir des mots au Moyen Âge, ed. by N. Bériou, J.-P. Boudet, I. Rosier-Catach, Turnhout 2014

Bériou 2018: N. Bériou, Religion et communication. Un autre regard sur la prédication au Moyen Âge, Genève 2018

Borch 2004: Text and Voice. The Rhetoric of Authority in the Middle Ages, ed. by M. Borch, Odense 2004

Brenk 2011: B. Brenk, Rhetorik, Anspruch und Funktion der Cappella Palatina in Palermo, in Die Cappella Palatina in Palermo. Geschichte, Kunst, Funktionen, ed. by T. Dittelbach, Künzelsau 2011, 242-271

Brassat 2005: Bild-Rhetorik, ed. by W. Brassat, Tübingen 2005 
Burkard 2019: T. Burkard, Rhetorik im Mittelalter und im Humanismus, in Handbuch Antike Rhetorik, ed. by M. Erler, C. Tornau, Berlin, 2019, 697-760

Burke 2001: P. Burke, Eyewitnessing. The Uses of Images as Historical Evidence, London 2001

Camargo 2012: M. Camargo, Essays on Medieval Rhetoric, Farnham 2012

Cammarosano et al. 2016: Art de la lettre et lettre d'art. Epistolaire politique III, ed. by P. Cammarosano, B. Dumézil, S. Giovanni, L. Vissière, Trieste 2016

Carracedo Fraga 2002: J. Carracedo Fraga, La retorica en la Hispania visigotica, «Euphrosyne» 30 (2002), 115-130

Carruthers 2010: M.J. Carruthers, Rhetoric beyond words. Delight and Persuasion in the arts of the Middle Ages, New York 2010

Chandelier-Robert 2015: Frontières des savoirs en Italie à l'époque des premières universités (XIII ${ }^{e}-X V^{e}$ siècles), ed. by J. Chandelier, A. Robert, Roma 2015

Chastang 2008: P. Chastang, L'archéologie du texte médiéval, «Annales. Histoire, Sciences Sociales 63/2 (2008), 245-269

Chastang-Otchakovsy-Laurens 2017: P. Chastang, F. Otchakovsy-Laurens, Les statuts urbains de Marseille. Acteurs, rhétorique et mise par écrit de la norme, in La confection des statuts dans les sociétés méditerranéennes de l'Occident (XII ${ }^{e} X V^{e}$ siècle), Paris 2017, 15-40

Cirier 2007: A. Cirier, Diplomazia e retorica comunale. La comunicazione attraverso lo spionaggio politico nell'Italia medievale (secc. XII-XIII), in Comunicazione e propaganda nei secoli XII e XIII. Atti del Convegno internazionale (Messina, 2426 maggio 2007), ed. by R. Castano, F. Latella, T. Sorrenti, Roma 2007, 199-216

Civra 2009: F. Civra, Musica poetica. Retorica e musica nel periodo della Riforma, Lucca 2009

Clark 2017: The Fifteenth Century. Writing, Records and Rhetoric, ed. by L. Clark, Woodbridge 2017

Cortelazzo 1983: Retorica e classi sociali. Atti del IX Convegno internuniversitario di studi, Bressanone 1981, ed. by M.A. Cortelazzo, Padova 1983

Coste et al. 2012: La rhétorique médicale à travers les siècles. Actes du colloque international de Paris, 9 et 10 octobre 2008, ed. by J. Coste, D. Jacquart, J. Pigeaud, Genève 2012

Couchmann-Morton Crabb 2005: Women's Letters Across Europe (1400-1700). Form and Persuasion, ed. by J. Couchman, A. Morton Crabb, Burlington 2005

D'Acunto 2009: N. D'Acunto, Pier Damiani fra retorica e tensione eremitica, in Sassoferrato. Alla memoria del professor Alberto Grilli, ed. by F. Bertini, Sassoferrato 2009, 35-45

D'Acunto 2012: N. D'Acunto, Le forme della comunicazione negli ordini religiosi del XII e XIII secolo. Il centro, in Die Ordnung der Kommunikation und die Kommunikation der Ordnungen, I, Netzwerke: Klöster und Ordnen im Europa des 12. und 13. Jahrhunderts, ed. by C. Andenna, K. Herbers, G. Melvile, Stuttgart 2012, 253-260 
D'Acunto 2018: Argomenti di natura giuridica e strumenti della comuicazione pubblica durante la lotta per le investiture, in Verbum e ius. Predicazione e sistemi giuridici nell'occidente medievale $=$ Preaching and Legal Frameworks in the Middle Ages, ed. by L. Gaffuri, R.M. Parrinello, Firenze 2018, 89-108

David-Berlioz 1980: Rhétorique et histoire. L'«exemplum» et le modèle de comportement dans le discours antique et médiéval, ed. by J.-M. David, J. Berlioz, «Mélanges de l'École Française de Rome» 92/1 (1980), 1-179

De Jong 2019: M. De Jong, Epitaph for an Era. Politics and Rhetoric in the Carolingian World, Cambridge 2019

Delcorno 1974: C. Delcorno, La predicazione in età comunale, Firenze 1975

Delcorno 1989: C. Delcorno, Exemplum e letteratura. Tra Medioevo e Rinascimento, Bologna 1989

Delcorno 2009: C. Delcorno, «Quasi quidam cantus». Studi sulla predicazione medievale, Firenze 2009

Delcorno 2015a: C. Delcorno, Comunicare dal pulpito (sec. XIII-XV), in Comunicare nel Medioevo. La conoscenza e l'uso delle lingue nei secoli XII-XV. Atti del convegno di studio, Ascoli Piceno, 28-30 novembre 2013, ed. by I. Lori Sanfilippo, G. Pinto, 183-208

Delcorno 2015b: C. Delcorno, Apogeo e crisi della predicazione francescana tra Quattro e Cinqucento, «Studi Francescani» 112 (2015), 399-440

Delle Donne 2003: Nicola da Rocca, Epistolae, ed. by F. Delle Donne, Firenze 2003

Delle Donne 2004: F. Delle Donne, Una «costellazione» di epistolari del secolo XIII. Tommaso di Capua, Pier della Vigna, Nicola da Rocca, «Filologia Mediolatina» 11 (2004), 143-160

Delle Donne-Santi 2013: Dall'«ars dictaminis» al preumanesimo? Per un profilo letterario del secolo XIII, ed. by F. Delle Donne, F. Santi, Firenze 2013

Delle Donne 2016: Le parole del potere e il potere delle parole. Le epistole della cancelleria sveva, in Art de la lettre et lettre d'art. Epistolaire politique III, ed. by P. Cammarosano, B. Dumézil, S. Giovanni, L. Vissière, Trieste 2016, 161-174

Delle Donne-Revest 2016: - L'essor de la rhétorique humaniste. Réseaux, modèles et vecteurs, ed. by F. Delle Donne e C. Revest, «Mélanges de l'École Française de Rome. Moyen Âge» 128/1 (2016)

Debbyt 2012: N.B.-A. Debby, Retorica visual. Imagenes de sarracenos en iglesias florentinas, «Anuario de estudios medievales» 42 (2012), 7-28

Di Lorenzo 2009: A. Di Lorenzo, Tra retorica e formularità. Le arenghe degli atti di donazione italo-greci di età normanna nel Mezzogiorno, «Medioevo Greco» 9 (2009), 107-178

Dittelbach 2006: T. Dittelbach, Rhetorik in Stein. Der normannische Osterleuchter der Cappella Palatina in Palermo, in Visualisierungen von Herrschaft. Frühmittelalterliche Residenzen, Gestalt und Zeremoniell, ed. by F. Alto Bauer, Istanbul 2006, 329-351 
Dodd et al. 2014: G. Dodd, M. Phillips, H. Killick, Multiple-clause Petitions to the English Parliament in the Later Middle Ages. Instruments of Pragmatism or Persuasion?, «Journal of Medieval History» 40 (2014), 176-194

Dostalova 1995: R. Dostalova, Der Einfluss der Rhetorik auf die Objektivität der historische Information in den Werken byzantinischen Historiker, «Byzantinoslavica» 56 (1995), 291-303

Faini 2015: E. Faini, Annali cittadini, memoria pubblica ed eloquenza civile in età comunale, «Storica» 60-61 (2015), 109-142

Faini 2018: E. Faini, Italica gens. Memoria e immaginario politico dei cavaliericittadini (secoli XII-XIII), Roma 2018

Faini [forthcoming]: E. Faini, Il Comune e il suo contrario. Assenza, presenza, scelta nel lessico politico (secolo XII), forthcoming

Fichtenau 1957: H. Fichtenau, Arenga. Spätantike und Mittelalter im Spiegel von Urkundenformeln, Graz 1957

Folin 2013: M. Folin, Edifici comunali e retorica civica a Firenze (secoli XII-XV), in Dal giglio a David. Arte civica a Firenze fra Medioevo e Rinascimento, ed. by M.M. Donato, D. Parenti, Firenze 2013, 56-65

Fowden 2014: G. Fowden, Before and after Muhammad. The First Millennium Refocused, Princeton 2014

Fried 1997: Dialektik und Rhetorik im früheren und hohen Mittelalter. Rezeption, Überlieferung und gesellschaftliche Wirkung antiker Gelehrsamkeit vornehmlich im 9. und 12. Jahrhundert, ed. by J. Fried, München 1997

Fricke-Krass 2015: The public in the Picture. Involving the Beholder in Antique, Islamic, Byzantine and Western Medieval and Renaissance Art, ed. by B. Fricke, U. Krass, Zürich 2015, 205-230

Fumaroli 1980: M. Fumaroli, L'âge de l'éloquence. Rhétorique et "res literaria» de la Renaissance au seuil de l'époque classique, Paris 1980

Gadebusch Bondio-Ricklin 2008: Exempla medicorum. Die Ärzte und ihre Beispiele (14.-18. Jahrhundert), ed. by M. Gadebusch Bondio, T. Ricklin, Firenze 2008

Gaonkar 1990: D.P. Gaonkar, Rhetoric and Its Double. Reflections on the Rhetorical Turn in the Human Sciences, in The Rhetorical Turn. Invention and Persuasion in the Conduct of Inquiry, ed. by H.W. Simons, Chicago 1990, 341-366

Gioanni-Cammarosano 2013: La corrispondenza epistolare in Italia, ed. by S. Gioanni, P. Cammarosano, Trieste 2013

Gonzalez Sanchez 2013: N. Gonzalez Sanchez, Mujeres y retorica latina. Aproximacion, analisis y estudio de los epistolarios latinos medievales femininos, in Ser mujer en la ciudad medieval europea, ed. by B. Arizaga Bolumburu, A.A.A. de Andrade, J.A. Solorzano Telechea, Logrono 2013, 491-514

Grasso 2010: C. Grasso, Ars Praedicandi e crociata nella predicazione dei magistri parigini, in Come l'orco della fiaba. Studi per Franco Cardini, ed. by M. Montesano, Firenze 2010, 141-150 
Grasso 2013: C. Grasso, La delega papale alla predicazione della crociata al tempo del IV concilio Lateranense, «Rivista di Storia della Chiesa in Italia» 67 (2013), 37-54

Grasso 2014: C. Grasso, Legati papali e predicatori della quinta crociata, in Legati, delegati e l'impresa d'Oltremare (secoli XII-XIII), ed. by M.P. Alberzoni, P. Montaubin, Turnhout 2014, 262-282

Grévin 2008a: B. Grévin, Rhétorique du pouvoir médiéval. Les «Lettres» de Pierre de la Vigne et la formation du langage politique européen (XIII ${ }^{e}-X V^{e}$ siècle), Roma 2008

Grévin 2008b: B. Grévin, Les mystères rhétoriques de l'État médiéval. L'écriture du pouvoir en Europe occidentale (XIII $-X V^{e}$ siècle), «Annales. Histoire, Sciences Sociales» 63/2 (2008), 271-300

Grévin-Turcan-Verkerk 2015: Le dictamen dans tout ses états. Perspectives de recherche sur la théorie et la pratique de l'«ars dictaminis», ed. by B. Grévin, A.M. Turcan-Verkerk, Turnhout 2015

Grévin-Hartmann 2020: - Der mittelalterliche Brief zwischen Norm und Praxis, ed. by B. Grévin, F. Hartmann, Köln 2020

Guyotjeannin 2004: La langue des actes. Actes du XI Congrès international de diplomatique (Troyes, 11-13 septembre 2003), ed. by O. Guyotjeannin, Paris 2004

Hartmann 2011: Funktionen der Beredsamkeit = Funzioni dell'eloquenza nell'Italia comunale, ed. by F. Hartmann, Göttingen 2011

Hartmann 2013: F. Hartmann, Ars dictaminis. Briefsteller und verbale Kommunikation in den italienischen Stadtkommunen des 11. bis 13. Jahrhunderts, Ostfildern 2013

Hartmann 2019: F. Hartmann, Il linguaggio del consenso nell'elaborazione della retorica comunale, in Costruire consenso. Modelli, pratiche, linguaggi tra Medioevo ed età moderna, ed. by di M.P. Alberzoni, R. Lambertini, Milano 2019, $145-158$

Helmrat 2006: J. Helmrath, Der europäische Humanismus und die Funktion der Rhetorik, in Funktionen des Humanismus. Studien zum Nutzen des Neuen in der humanistischen Kultur, ed. by T. Maissen, G. Walther, Göttingen 2006, 18-49

Herde 2008: P. Herde, Friedrich II. und das Papsttum. Politik und Rhetorik, in Kaiser Friedrich II. (1194-1250). Welt und Kultur des Mittelmeerraums, ed. by M. Fansa, Mainz 2008, 52-65

Hilsdale 2003: C.J. Hilsdale, Diplomacy by design. Rhetorical strategies of the Byzantine gift, Chicago 2003

Hohmann 1998: H. Hohmann, Logic and Rhetoric in Legal Argumentation. Some Medieval Perspectives, «Argumentation» 12 (1998), 39-55

Hold 2001: H. Hold, Cural- und Gratial-Rhetorik. Untersuchungen an Arengen in Schreiben des Avignoneser Papsttums, 2 voll., Wien 2001

Hold 2006: H. Hold, Päpstliche Arengen-Rhetorik zur Avignoneser Zeit. Integralistisch angelegte Kultur-Manipulation?, in Inkulturation. Historische Beispiele und theologische Reflexionen zur Flexibilität und Widerständigkeit des Christlichen, ed. by R. Klieber, M. Stowasser, Wien 2006, 129-139 
Holzapfl 2008: J. Holzapfl, Kanzleikorrespondenz des späten Mittelalters in Bayern. Schriftlichkeit, Sprache und politische Rhetorik, München 2008

Hostein 2003: A. Hostein, Histoire et rhétorique. Rappels historiographiques et états des lieux, «Hypothèses» 6 (2003), 219-234

Internullo 2019: D. Internullo, La citazione in cancelleria. Il comune di Roma nel Medioevo, «Parole Rubate» 19 (2019), 55-79

Jeffreys 2003: Rhetoric in Byzantium. Papers from the thirty-fifth Spring Symposium of Byzantine Studies, Exeter College, University of Oxford, March 2001, ed. by E.M. Jeffreys, Aldershot 2003

Kapp 1990: Die Sprache der Zeichen und Bilder. Rhetorik und nonverbale Kommunikation in der frühen Neuzeit, ed. by V. Kapp, Marburg 1990

Knape 207: Bildrhetorik. Zweites Tübinger Rhetorikgespräch am 4. und 6. Oktober 2002, ed. by J. Knape, Baden 2007

Kofler-Töchterle 2005: Die antike Rhetorik in der europäischen Geistesgeschichte, ed. by W. Kofler, K. Töchterle, Innsbruck 2005

Koutrakou 1994: N. Koutrakou, La propagande impériale byzantine. Persuasion et réaction (VIII ${ }^{e} X^{e}$ siècles), Athene 1994

Kraus 2015: J. Kraus, Rhetoric in European Culture and Beyond, Praha 2015

Kristeller 1969: P.O. Kristeller, Der italienische Humanismus und seine Bedeutung, Basel 1969

Kristeller 1981: - P.O. Kristeller, Studien zur Geschichte der Rhetorik und zum Begriff des Menschen in der Renaissance, Göttingen 1981

Kuhn 1962: T. Kuhn, The Structure of Scientific Revolution, Chicago 1962

Lazzarini 2018: I. Lazzarini, Epistolarità dinastica e autografia femminile. La corrispondenza delle principesse di casa Gonzaga (fine XIV-primo XVI secolo) in Donne Gonzaga a corte. Reti istituzionali, pratiche culturali e affari di governo, ed. by C. Continisio, R. Tamalio, Roma 2018, 49-62

Le Goff 1988: J. Le Goff, L'exemplum et la rhétorique de la prédication aux XIII et $X I V^{e}$ siècles, in Retorica e poetica tra i secoli XII e XIV. Atti del secondo convegno internazionale di studi sull'Associazione per il Medioevo e l'Umanesimo Latini (AMUL) in onore e memoria di Ezio Franceschini (Trento e Rovereto 2-5 ottobre 1985), ed. by C. Leonardi, E. Menestò, Perugia-Firenze 1988, 3-29

Lewis 1999: S. Lewis, The Rhetoric of Power in the Bayeux Tapestry, Cambridge 1999

Mack 2011: P. Mack, A History of Renaissance Rhetoric (1380-1620), Oxford 2011

Maldina 2011: N. Maldina, La retorica dalle università alle città, in Il Medioevo. Castelli, mercanti, poeti, ed. by U. Eco, Milano 2011, 387-351

Marcozzi 2017: Dante e la retorica, ed. by L. Marcozzi, Ravenna 2017

Mari 2019: T. Mari, Working on the Minuts of Late Antique Church Councils. A Methodological Framework, «Journal for Late Antique Religion and Culture» 13 (2019), 42-59 
Marietti 2002: La science du bien dire. Rhétorique et rhétoriciens au Moyen Âge, ed. by M. Marietti, Paris 2002

Menant 2019: Qu'est-ce que le peuple au Moyen Âge?, «Mélanges de l'École Française de Rome» 131/1 (2019)

Menzel 1998: M. Menzel, Predigt und Geschichte. Historische Exempel in der geistlichen Rhetorik des Mittelalters, Köln 1998

Metodieva 1993: L. Metodieva, La naissance de la rhétorique bulgare. L'influence de l'oeuvre de Jean Chrysostome et des grands cappadociens sur le développement de la prose rhétorique bulgare ancienne aux IX et $X^{e}$ siècles, «Rhetorica» 11 (1993), 27-41

Miglio 2008: L. Miglio, Governare l'alfabeto. Donne, scrittura e libri nel Medioevo, Roma 2008

Morsel 2019: J. Morsel, Le diable est-il dans les détails? L'historien, l'indice et le cas particulier, Paris 2019

Morsel 2016: J. Morsel, Traces, quelles traces? Réflexions pour une Histoire non passéiste, Paris 2016

Morsel 2007: J. Morsel, L'Histoire (du Moyen Âge) est un sport de combat, Paris, LAMOP, 2007

Murphy 1983: Renaissance Eloquence. Studies in the Theory and Practice of Renaissance Rhetoric, ed. by J.J. Murphy, Berkeley 1983

Nicoud 2013: M. Nicoud, Medici, lettere e pazienti. Pratica medica e retorica nella corrispondenza della cancelleria sforzesca, in Étre médecin à la cour (Italie, France, Espagne, XIII ${ }^{e}-X V I I I^{e}$ siècle), ed. by E. Andretta, M. Nicoud, Firenze 2013, 213-233

Noille 2018: - C. Noille, La narration dans la rhétorique judiciaire. Formes possibles et usages modélisés, in Les recueils de plaidoyez à la Renaissance, ed. by G. Cazals, Genève 2018, 21-38

Oakley Brown-Wilkinson 2009: The Rituals and Rhetoric of Queenship. Medieval to early Modern, ed. by L. Oakley-Brown, L.J. Wilkinson, Dublin 2009

Perez Monzon et al. 2018: Retorica artistica en el tardogotico castellano. La capilla funebre de Alvaro de Luna en contexto, ed. by O. Pérez Monzon, M. Miquel Juan, M. Martin Gil, Madrid 2018

Potestà 2007: G.L. Potestà, Le forme di una retorica profetica e apocalittica. I Frati Minori e il Gioachimismo (secoli XIII-XIV), in El fuego y la palabra. San Vincente Ferrer en el 550 aniversario. Actas del Ier Simposium Internacional Vicentino, Valencia, 26-29 de abril 2005, ed. by E. Callado Estela, Valencia 2007, 233-256

Plett 1993: Renaissance-Rhetorik = Renaissance Rhetoric, ed. by H.F. Plett, Berlin 1993

Resl 2008: B. Resl, Illustration and Persuasion in Southern Italian Cartularies (c. 1100), in Strategies of Writing. Studies on Text and Trust in the Middle Ages. Papers from «Trust in Writing in the Middle Ages, Utrecht 28-29 november 2002», ed. by P. Schulte, M. Mostert, I. van Renswoude, Turnhout 2008, 95-110 
Revest 2013a: C. Revest, La naissance de l'humanisme comme mouvement au tournant du XV $V^{e}$ siècle, «Annales. Histoire, Sciences Sociales» 68/3 (2013), 665-696

Revest 2013b: C. Revest, Naissance du cicéronianisme et émergence de l'humanisme comme culture dominante. Réflexions pour une histoire de la rhétorique humaniste comme pratique sociale, «Mélanges de l'École Française de Rome. Moyen Âge» $125 / 2(2013)$

Roguet 2017: A. Roguet, Rhétorique et pouvoir. Les chancelleries française et allemande sous les règnes de Louis VII et Frédéric Barberousse, in Aux sources du pouvoir. Voir, approcher, comprendre le pouvoir politique au Moyen Âge, ed. by S. Gouguenheim, Paris 2017, 223-244

Romano 2007: R. Romano, La teoria della retorica a Bisanzio dal tardoantico alla rinascenza macedone, «Porphyra» 9 (2007), 107-125

Romoli 2009: F. Romoli, Predicatori nelle terre slavo-orientali (XI-XIII sec.). Retorica e strategie comunicative, Firenze 2009

Rubinstein 1990: N. Rubinstein, Il Bruni a Firenze. Retorica e politica, in Leonardo Bruni. Cancelliere della Repubblica di Firenze. Convegno di studi, Firenze 27-29 ottobre 1987, ed. by P. Viti, Firenze 1990, 15-28

Russo 2019: - C. Russo, Firenze nuova Roma. Arte retorica e impegno civile nelle miscellanee di prose del primo Rinascimento, Firenze 2019

Schellewald 2012: B.M. Schellewald, Rhetorik um 1200. Die Ausmalung der Kirche von Kintsvisi (Georgien) und Byzanz, in Schnittpunkt Slavistik. Ost und West im wissenschaftlichen Dialog. Festgabe für Helmut Keipert zum 70. Geburtstag, ed. by I. Podtergera, Bonn 2012, II, 363-374

Schnell 2010: R. Schnell, Gender und Rhetorik in Mittelalter und Früher Neuzeit. Zur Kommunikation der Geschlechter, in Rhetoric und Gender, ed. by D. Bischoff, M. Wagner-Egelhaaf, Berlin 2010, 1-18

Sennis 2013: - Sennis, Linguaggi della persuasione. Le visioni soprannaturali nel mondo monastico medievale, in Ricerca come incontro. Archeologi, paleografi e storici per Paolo Delogu, ed. by G. Barone, A. Esposito, C. Frova, Roma 2013, 227-243

Senséby 2004: C. Senséby, Pratiques judiciaires et rhétorique monastique à la lumière de notices ligériennes (fin XI siècle), «Revue Historique» 306 (2004), 3-47

Serverat 1997: V. Serverat, La Pourpre et la glèbe. Rhétorique des états de la société dans l'Espagne médiévale, Grénoble 1997

Shepard 1999: L.A. Shepard, Courting Power. Persuasion and Politics in the early Thirteenth Century, New York 1999

Simons 1990: The Rhetorical Turn. Invention and Persuasion in the Conduct of Inquiry, ed. by H.W. Simons, Chicago 1990

Smirnova-Polo de Beaulieu 2019: - V. Smirnova, M.-A. Polo de Beaulieu, Lire et faire lire des recueils d'exempla. Entre persuasion cistercienne et efficace dominicaine, in Le texte médiéval dans le processus de communication, ed. by L.V. Evdokimova, A. Marchandisse, Paris 2019, 133-154 
Smith-Killick 2018: Petitions and strategies of persuasion in the Middle Ages. The English crown and the church (1200-1550), ed. by T.W. Smith, H. Killick, Woodbridge 2018

Stella 2009: F. Stella, Retorica e agiografia come strumenti per la costruzione dell'identità civica. Arezzo e Bologna fra Chiesa e Studium, in Civis - Civitas. Cittadinanza politico-istituzionale e identità socio-culturale da Roma alla prima età moderna. Atti del seminario internazionale, Siena-Montepulciano, 10-13 luglio 2008, Montepulciano 2009, 265-284

Strack-Knödler 2011: Rhetorik in Mittelalter und Renaissance. Konzepte - PraxisDiversität, ed. by G. Strack, J. Knödler, München 2011

Struever 2009: - N.S. Struever, The History of Rhetoric and the Rhetoric of History, Aldershot 2009

Sultan 2005: A. Sultan, «En conjunction de science». Musique et rhétorique à la fin du Moyen Âge, Paris 2005

Tanzini 2014: L. Tanzini, A consiglio. La vita politica nell'Italia dei comuni, RomaBari 2014

Vaillancourt 2003: L. Vaillancourt, La lettre familière au XVI siècle. Rhétorique humaniste de l'épistolaire, Paris 2003

van Renswoude 2019: I. van Renswoude, The Rhetoric of Free Speech in Late Antiquity and the Early Middle Ages, Cambridge 2019

Vasoli 1999: C. Vasoli, L'humanisme rhétorique en Italie au $X V^{e}$ siècle, in Histoire de la rhétorique dans l'Europe moderne (1450-1950), ed. by M. Fumaroli, Paris 1999, 45-129

von Moo-Melville 2006: Gesammelte Schriften zum Mittelalter Bd. 2. Rhetorik, Kommunikation und Medialität, ed. by P. von Moos, G. Melville, Berlin 2006

Vuilleumier Laurens-Laurens 2010: F. Vuilleumier Laurens, P. Laurens, L'âge de l'inscription. La rhétorique du monument en Europe du XV $V^{e}$ au XVII siècle, Paris 2010

Ward 2019: J.O. Ward, Classical Rhetoric in the Middle Ages. The Medieval Rhetors and their Art (400-1300), with Manuscript Survey to 1500 CE, Leiden 2019

Winau 1965: R. Winau, Formular und Rhetorik in den Urkunden Kaiser Ludwigs II, Bamberg 1965

Witt 2000: R. G. Witt, «In the Footsteps of the Ancients». The Origins of Humanism from Lovato to Bruni, Leiden 2000

Witt 2012: - R.G. Witt, The Two Latin Cultures and the Foundation of Renaissance Humanism in Medieval Italy, Cambridge 2012

Yilmaz 2007: K. Yilmaz, Introducing the «Linguistic Turn» to History Education, «International Education Journal» 8/1 (2007), 270-278

Zarri 1999: Per lettera. La scrittura epistolare femminile tra archivio e tipografia secoli $X V-X V I I$, ed. by G. Zarri, Roma 1999 


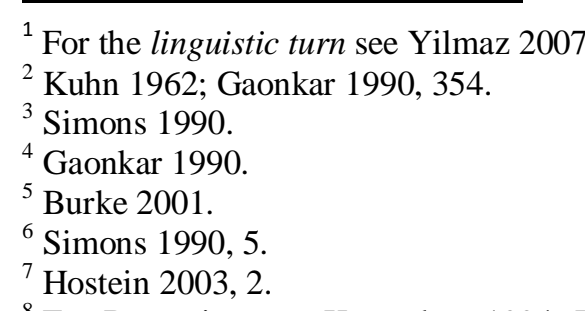

${ }^{8}$ For Byzantium see Koutrakou 1994; Dostalova 1995; Hilsdale 2003. For communal Italy see Artifoni 1993, 2002, 2011; Cirier 2007; Tanzini 2014; Faini 2015, 2018; Hartmann 2013, 2019. For empire and papacy see Shepard 1999; Herde 2008; Grévin 2008a. For the early Middle Ages see De Jong 2019.

${ }^{9}$ For reflections on diplomatics, see Fichtenau 1957 and Winau 1965. The above-mentioned studies, well contextualized also in the so-called «archeology of medieval text» (Chastang 2008), are: Delle Donne 2003, 2004, 2016; Alfonso Anton 2007 and Aller Soriano 2009; Grévin 2008a and 2008b; Resl 2008; Di Lorenzo 2009; Dodd et al. 2014; Barret-Grévin 2014; Clark 2017; Chastang-Otchakovsky 2017; Roguet 2017; Smith-Killick 2018; Internullo 2019. For papacy and empire see, beyond Grévin: Hold 2001 and 2006, Holzapfl 2008. Collective works are Guyotjeannin 2004; Gioanni-Cammarosano 2013; Cammarosano et al. 2016 and now also Grévin-Hartmann 2020.

${ }^{10}$ Cortelazzo 1983; Metodieva 1993; Schellewald 2012; Serverat 1997; Menant 2019; Faini c.d.s.; Stella 2009; Oakley Brown-Wilkinson 2009; Schnell 2010; Gonzalez Sanchez 2013; Couchman-Morton Crabb 2005. For women's writing in the Middle Ages and the Renaissance see also Zarri 1999; Miglio 2008; Lazzarini 2018.

${ }^{11}$ For the reconsideration of images see Burke 2001. The here mentioned researches are Lewis 1999; Dittelbach 2006; Brenk 2011; Debby 2012; Folin 2013; Perez Monzon et al. 2018; Carruthers 2010. For some collective reflections see Kapp 1990; Brassat 2005 e Knape 2007; Vuilleumier Laurens-Laurens 2010; Fricke-Krass 2015.

${ }^{12}$ David-Berlioz 1980; Le Goff 1988; Bériou 2018; Bériou et al. 2014; Menzel 1998; Delcorno 1974, 1989, 2009, 2015a, 2015b; Potestà 2007; D'Acunto 2009, 2012, 2018; Romoli 2009; Sennis 2013; Grasso 2010, 2013, 2014; Smirnova-Polo de Beaulieu 2019.

${ }^{13}$ Fumaroli 1980; Kristeller 1969, 1981; Witt 2000, 2012; Revest 2013a, 2013b; Delle Donne-Revest 2016. Other important works are Murphy 1983; Rubinstein 1990; Plett 1993; Vasoli 1999; Vaillancourt 2003; Helmrath 2011; Mack 2011; Delle Donne-Santi 2013; Russo 2019.

${ }^{14}$ Marcozzi 2017; Chandelier-Robert 2015; Alessio-Losappio 2018; Hartmann 2011; Strack-Knödler 2011; Grévin-Turcan-Verkerk 2015; van Renswoude 2019. For Riedlberger's project and the conciliar proceedings see <https://cordis.europa.eu/project/id/677638/results> and Mari 2019. See also Acerbi 2011. For further recent studies on medieval rhetoric see Fried 1997, Carracedo Fraga 2002, Jeffreys 2003, Borch 2004, Kofler-Töchterle 2005, von Moos-Melville 2006; Romano 2007; Struever 2009; Maldina 2011; Camargo 2012; Kraus 2015; Ward 2019; Burkard 2019. For the «first millennium» see Fowden 2014. 